\title{
TINJAUAN HUKUM ISLAM DAN UNDANG-UNDANG NO 1 TAHUN 1974 \\ TERHADAP AKIBAT HUKUM PERKAWINAN \\ ANTAR PENGANUT AGAMA
}

\section{Joni Zulhendra}

\begin{abstract}
Marriage is an obligation for those who have been able to marriage, to avoid immoral or a sin, and will bring a happy life prosperous, sakinah, mawaddah warahmah. Interfaith marriage as a result of lower levels of religious one husband or wife who causes problems between their religion is not a major priority, because happiness in domestic life for interfaith marriage is the fulfillment of the obligations of husband and wife, as measured by economic needs, psychological and spiritual. In Islamic law, and Law No. 1 of 1974 prohibits the majority of scholars into marriage with a man who is not Muslim, meaning that interfaith marriage is prohibited in accordance with the provisions of Islamic law.
\end{abstract}

Keywords : Due to inter-faith marriage law.

\section{A. PENDAhULUAN}

Sebagai ciptaan Allah SWT manusia yang mempunyai rasa cinta kasih dan sayang merupakan anugerah illahi. Rasa cinta kasih dan sayang ini kadang-kadang tidak mengenal perbedaan warna kulit, golongan, keturunan, suku, bangsa ataupun agama, oleh sebab itu perkawinan antar umat beragama kini suah banyak terjadi pada masyarakat Indonesia.

Perkawianan merupakan anjuran dari Tuhan Yang Maha Esa Pencipta sebagai mana dalam firmannya dalam surat Annur : 32 "dan kawinilah orang-orang yang sendirian di antara kamu dan orang-orang yang layak berkawin dari hamba-hamba sahayamu yang lelaki dan hamba-hamba sahayamu yang perempuan. Jika mereka miskin, Allah akan memampukan mereka dengan karuniaNya. Dan Allah maha luas pemberiannya lagi maha mengetahui.

Ayat tersebut di atas menerangkan, bahwa Allah SWT menyegerakan agar manusia baik laki-laki maupun perempuan yang sudah waktunya (yang tidak beristeri dan bersuami) untuk melakukan perkawinan, karena untuk menjaga kehormatannya, sehingga akan terbentuk keluarga yang sehat dan terhormat dengan persyaratan perkawinan terpenuhi. Tujuan perkawinan menurut agama Islam yaitu untuk memperoleh perkawinan yang sah, menghindari perbuatan maksiat, menimbulkan rasa cinta (sayang) sebagai sunnah Rasul. Sebagaimana sabdanya : Perkawinan adalah salah satu Sunnahku. Barang siapa tidak menyukai sunnahku, maka sesungguhnya ia tidak termasuk umat ku. (HR.Muslim). 
Selain anjuran, pernikahan itu merupakan kewajiban bagi yang sudah mampu untuk nikah, agar terhindar dari maksiat atau dosa, dan akan membawa kehidupan yang bahagia sejahtera, sakinah, mawaddah warahmah. Sesuai dengan firman Allah SWT, dalam surat Arrum ayat 21 yang artinya : Dan di antara tanda-tandakekuasan-Nya ialah dia menciptakan untukmu isteri-isteri dari jenismu sendiri, supaya kamu cendrung dan merasa tenteram kepadanya dan dijadikannya di antaramu rasa kasih dan sayang. Sesungguhnya pada yang demikian itu benar-benar terdapat tanda-tanda bagi kaum yang berfikir.

Perkawinan yang akan membawa ketenangan lahiriyah dan bathiniyah itu, harus sama keyakinan agamanya, tidak boleh berbeda agama, sesuai dengan Firman Allah Surat AlBaqarah : 221, yang artinya : dan janganlah kamu nikahi wanita-wanita musyrik, sebelum mereka beriman. Sesungguhnya budak beriman lebih baik dari pada wanita musyrik, walaupun dia menarik hatimu. Dan jangan kamu menikahkan orang-orang musyrik dengan wanita mukmin sebelum mereka beriman. Sesungguhnya budak yang mukmin lebih baik dari orang musyrik walaupun dia menarik hatimu. Mereka mengajak ke neraka, sedang Allah mengajak ke syurga dan ampunan dengan izinNya. Dan Allah menerangkan ayat-ayatnya (perintah-perintah-nya kepada manusia supaya mereka mengambil pelajaran.

Dalam Undang-undang No 1 Tahun 1974 tentang perkawinan, pasal 1 menyebutkan bahwa : Perkawinan adalah ikatan lahir batin antara seorang pria dan seorang wanita sebagai suami isteri dengan tujuan mebentuk keluarga atau rumah tangga yang bahagia dan kekal berdasarkan Ketuhanan Yang Maha Esa. Pasal 2 ayat (1) menyebutkan bahwa : Perkawinan adalah sah, apabila dilakukan menurut hukum masing-masing agamnya dan kepercayaannya itu. Oleh sebab itu, perkawinan antar penganut agama, dengan berbagai macam alasannya seperti lebih baik dari pada membiarkan kumpul kebo. Ada juga beranggapan bahwa ini mungkin sudah jodohnya dan merupakan hak asasi manusia. Alasan tersebut tidak dapat dipertanggungjawabkan, baik secara hukum Islam maupun hukum Negara, karena perkawinan akan dipertanggungjawabkan dihadapan Allah SWT sebagai pencipta yang telah mengatur kehidupan dengan segala kesempurnaan-Nya.

Kasus-kasus yang terjadi di Indonesia yang berada di kota-kota besar, di mana masyarakatnya majemuk dan kurang mengindahkan hukum Agama dan lebih berpandangan terhadap hak asasi manusia dalam urusan pernikahan, kasus-kasus juga dapat dilihat di media cetak atau elektronik yang melakukan perkawinan antar penganut agama yang dilakukan oleh kalangan artis atau selebritis, mereka melangsungkan pernikahan dengan wanita atau laki- 
laki yang berbeda keyakinan atau berbeda agama. Berdasarkan latar belakang di atas, maka dapat dirumuskan masalah pokok sebagai berikut : bagaimana akibat hukum dari perkawinan antar penganut agama dalam tinjauan hukum Islam dan Undang-undang No 1 tahun 1974.

\section{B. PEMBAHASAN}

\section{Tinjauan tentang Perkawinan}

Sejak dilahirkan manusia selalu hidup bersama dengan manusia lainnya didalam suatu pergaulan hidup. Hidup bersama antara seorang pria dan seorang wanita yang memenuhi syarat-syarat tertentu disebut perkawinan. Suatu kepercayaan yang di yakini oleh sebagian besar manusia didunia, bahwa lahir, kawin dan mati adalah kodrat manusia. Perkawinan adalah ikatan yang suci antara pria dan wanita dalam suatu rumah tangga. Melalui perkawinan dua insan yang berbeda disatukan dengan segala kelebihan dan kekurangan masing-masing.

Nikah atau (kawin) menurut arti aslinya adalah hubungan seksual tetapi menurut majaz atau arti hukum ialah akad (perjanjian) yang menjadikan halal hubungan seksual sebagai suami isteri antara seorang pria dengan seorang wanita ${ }^{1}$

Ahmad Shalaby mengemukakan pemahamannya tentang makna perkawinan yang dikaitkan dengan arti dari Q.S Yaa Siin ayat 36 dan arti Q.S Al-Mu'min ayat 27 bahwa perkawinan adalah hukum alam yang tetap dan luas bidangnya yang mencakup setiap makhluk hidup, hukum tersebut membahagiakan setiap makhluk hidup dan masingmasing jenis akan memperoleh bagian, yaitu suatu rahasia yang berbeda dengan rahasia yang diberikan kepada lawan jenisnya. ${ }^{2}$

Ensiklopedia Hukum Islam dikatakan Perkawinan adalah merupakan salah satu upaya untuk menyalurkan naluri seksual suami isteri dalam sebuah rumah tangga sekaligus sarana untuk menghasilkan keturunan yang dapat menjamin kelangsungan eksistensii manusia di bumi. $^{3}$

Perkawinan yang disyaratkan oleh agama Islam dapat dilihat dari sudut hukum, sosial

dan agama. Perkawinan merupakan suatu perjanjian yang sangat kuat. Sudut sosial, perkawinan merupakan sarana untu meningkatkan status seseorang dalam masyarakat. Orang yang sudah berkeluarga lebih dihargai dari yang belum berkeluarga. Sudut agama,

\footnotetext{
${ }^{1}$ Musafir Husain Aj-jahrani, Poligami Dalam Berbagai Persepsi, Gema Insani Pres, Jakarta, 1996, Hal 13

${ }^{2}$ Ahmad Shalaby, Kehidupan Sosial Dalam Pemikiran Islam, Amzah, Jakarta, 2001, Hal. 54

${ }^{3}$ Abdul Azis Dahlan, Ensiklopedia Hukum Islam, Ictiyar Baru Van Hoeve, Jakarta, 2006, Hal. 156
} 
perkawinan dianggap sebagai suatu lembaga suci, sebab pasangan suami isteri itu selalu dihubungkan dengan nama Allah SWT sebagaimana tercantum dalam al-quran dalam surat an Nisaa' ayat 1. Dari pengertian inilah dihubungkan dengan syariat Islam yang ditinjau dari tiga sudut, maka tidaklah bertentangan sebab sebuah perkawinan harus berlandaskan pada ketentuan Allah SW, baik menyangkut tujuan perkawinan amupun sahnya suatu perkawinan.

Undang-undang nomor 1 Tahun 1974 tentang perkawinan di dalam Pasal 1 menentukan bahwa Perkawinan adalah ikatan lahir bathin antara seorang pria dengan seorang wanita sebagai suami isteri dengan tujuan membentuk keluarga yang bahagia dan kekal berdasarkan Ketuhanan Yang Maha Esa. Pasal di atas memuat dua unsur dalam merumuskan definisi perkawinan yaitu meliputi arti dan tujuan perkawinan. Arti perkawinan adalah ikatan lahir bathin antara seorang pria dengan seorang wanita sebagai suami isteri., sedangkan tujuan perkawinan adalah membentuk keluarga/rumah tangga yang bahagia dan kekal berdasarkan Ketuhanan Yang Maha Esa. Perkataan ikatan lahir bathin dimaksudkan bahwa perkawinan itu tidak hanya cukup dengan adanya ikatan lahir atau ikatan bathin saja, tetapi harus keduaduanya.

Bermacam-macam pendapat yang dikemukakan para pakar hukum mengenai pengertian perkawinan, namun seluruh pengertian tersebut pada dasarnya berbeda, dan perbedaan tersebut tidaklah memperlihatkan adanya pertentangan akan makna yang terkandung dalam perkawinan tersebut.

\section{Perkawinan Beda Agama dalam Hukum Indonesia}

Di Indonesia, Perkawinan Beda Agama, sebelum lahirnya Undang-undang Perkawinan / UUP No. 1 Tahun 1974 dikenal dengan sebutan "Perkawinan Campur", sebagaimana diatur pertama kali dalam Regeling op de gemengde Huwelijken, Staatblad 1898 No. 158, yang merupakan Peraturan Perkawinan Campur/PPC). Dalam PPC tersebut terdapat beberapa ketentuan tentang perkawinan campur (perkawinan beda agama): Pasal 1: Pelangsungan perkawinan antara orang-orang yang di Hindia Belanda tunduk kepada hukum yang berbeda, disebut Perkawinan Campur. Pasal 6 ayat (1): Perkawinan campur dilangsungkan menurut hukum yang berlaku atas suaminya, kecuali izin para calon mitra kawin yang selalu disyaratkan. Pasal 7 ayat (2): perbedaan agama, golongan, penduduk atau asal usul tidak dapat merupakan halangan pelangsungan perkawinan. Pasal-pasal 
tersebut di atas menegaskan tentang pengaturan perkawinan beda agama, bahkan disebutkan, perbedaan agama tidak dapat dijadikan alasan utnuk mencegah terjadinya perkawinan. PPC tersebut dikeluarkan secara khusus oleh Pemeriantah Kolonial Belanda guna mengantisipasi perbedaan golongan yang tertuang dalam Indische Staats Religing (ISR) 9 Ibid, h 19511 yang merupakan Peraturan Ketatanegaran Hindia. Pada Pasal 163 golongan penduduk dibedakan menjadi tiga golongan yaitu: golongan Eropa (teramasuk di dalamnya Jepang); golongan pribumi (Indonesia) dan golongan Timur Asing kecuali yang beragama Kristen10 . Perkawinan Campur sebagaimana dimaksud pada PPC S. 1898 No. 158 di atas, tidak dikenal dalam UU No. 1 Tahun 1974. Pasal yang dijadikan landasan perkawinan beda agama pada UUP adalah Pasal 2 ayat (1): Perkawinan adalah sah, apabila dilakukan menurut hukum masing-masing agamanya dan kepercayaannya itu; dan Pasal 8 hurup (f): perkawinan dilarang (f): mempunyai hubungan yang oleh agamanya atau peraturan lain yang berlaku dilarang kawin; serta Pasal 57: yang dimaksud dengan perkawinan campur dalam Undang-undang ini ialah perkawinan antara dua orang yang di Indonesia tunduk pada hukum yang berlainan, karena perbedaan kewarga-negaraan dan salah satu pihak berkewarganegaraan Indonesia.

\section{Status Hukum Perkawinan Beda Agama Dalam Undang-undang No 1 Tahun 1974}

Perkawinan Beda Agama menurut pemahaman para ahli dan praktisi hukum dalam Undang-Undang No. 1 Tahun 1974 secara garis besar dapat dijumpai tiga pandangan: Pertama, perkawinan beda agama tidak dapat dibenarkan dan merupakan pelanggaran terhadap UUP Pasal 2 ayat (1): Perkawinan adalah sah, apabila dilakukan menurut hukum masing-masing agamanya dan kepercayaannya itu; dan Pasal 8 hurup (f): bahwa perkawinan dilarang antara dua orang yang mempunyai hubungan yang oleh agamanya atau peraturan lain yan berlaku, dilarang kawin. Maka dengan pasal ini, perkawinan beda agama dianggap tidak sah dan batal demi hukum. Kedua, perkawinan beda agama adalah diperbolehkan, sah dan dapat dilangsunkan karena telah tercakup dalam perkawinan campuran, sebagaiman termaktub dalam Pasal 57 UUP, yaitu dua orang yang di Indonesia tunduk pada hukum yang berlainan. Menurut pandangan kedua ini, pasal tersebut tidak saja mengatur perkawinan antara dua orang yang memiliki kewarganegaran yang berbeda, akan tetapi juga mengatur perkawinan antara dua orang yang berbeda agama. 
Menurutnya, pelaksanaannya dilakukan menurut tata cara yang diatur oleh Pasal 6 PPC: (1) Perkawinan campur dilangsungkan menurut hukum yang berlaku untuk suami, kecuali izin dari kedua belah pihak bakal mempelai, yang seharusnya ada, dengan merujuk pada Pasal 66 UUP. Ketiga. UUP tidak mengatur masalah perkawinan antaragama. Oleh karena itu, apabila merujuk Pasal 66 UUP yang menekankan bahwa peraturan-peraturan lain yang mengatur tentang perkawinan, sejauh telah diatur dalam unadang-undang ini, maka dinyatakan tidak berlaku lagi. Namun karena UUP belum mengaturnya, maka peraturan-peraturan lama dapat diberlakukan kembali, sehingga masalah perkawinan beda agama harus berpedoman kepada peraturan pekawinan campur (PPC). ${ }^{4}$ Di samping ketiga pendapat tersebut, ada kelompok yang berpandangan bahwa UUP perlu disempurnakan, mengingat adanya kekosongan hukum tentang perkawinan beda agama.

Argumentasi yang dibangun kelompok tersebut didasarkan pada empat hal, yaitu: 1) UUP tidak mengatur perkawinan beda agama; 2) masyarakat Indonesia adalah masyarakat plural, sehingga perkawinan beda agama tidak dapat dihindarkan; 3) persoalan agama adalah bagian dari hak asasi seseorang; dan 4) kekosongan hukum dalam bidang perkawinan tidak dapat dibiarkan begitu saja, sebab akan mendorong terjadinya perzinahan terselubung melalui pintu kumpul kebo. Di sisi lain, mayoritas masyarakat Muslim di Indonesia berpandangan bahwa UUP tidak perlu disempurkan dengan mencantumkan hukum perkawinan beda agama dalam undang-undang tersebut, sebab menurut mereka, Unadang-undang No. 1 Tahun 1974 telah mengatur hukum perkawinan beda agama secara jelas dan tegas. Ungkapan ini ada benarnya, karena umat Islam sebagai penduduk mayoritas di Indonesia merasa diuntungkan oleh Pasal 2 ayat (1) UUP tersebut, karena dengan pasal tersebut tertutuplah kemungkinan untuk melakukan perkawinan secara "sekuler", dan tertutup pula kemungkinan seorang wanita muslimah untuk menikah dengan laki-laki non muslim, demikian halnya perkawinan seorang lakilaki muslim dengan perempuan musyrik, karena pernikahan tersebut dilarang (dianggap tidak sah) menurut hukum Islam. Sebenarnya, dengan adanya larangan untuk melangsungkan pernikahan beda agama tersebut, merupakan masalah penting bagi umat

\footnotetext{
${ }^{4}$ Lihat UUP No. 1 thn 1974 dan Abdul Halim Berkatullah dan Teguh Prasetyo, Hukum Islam Menjawab Tantangan Zaman yang Terus Berkembang, Yogyakarta, Pustaka Pelajar, 2006, hlm 147-148
} 
Islam karena peraturan perkawinan peninggalan Belanda (PPC) mengizinkan penduduk Indonesia untuk melakuan perkawinan beda agama. ${ }^{5}$

\section{Perkawinan Beda Agama dalam Kompilasi Hukum Islam}

Perkawinan beda agama dalam KHI diatur secara eksplisit dalam Pasal 40 huruf (c) yang menyatakan bahwa dilarang melangsungkan perkawinan antara seorang pria dengan seorang wanita karena keadaan tertentu; diantaranya, karena seorang wanita yang tidak beragama Islam. Dalam Pasal 44 disebutkan bahwa seorang wanita Islam dilarang melangsungkan perkawinan dengan seorang pria yang tidak beragama Islam. Berdasarkan dua pasal di atas, dapat dikatakan bahwa menurut KHI, seorang wanita non muslim apa pun agama yang dianutnya tidak boleh dinikahi oleh seorang pria yang beragama Islam, dan seorang wanita muslim tidak boleh dinikahi oleh seorang pria non muslim, baik dari kategori ahli kitab atau pun bukan ahli kitab. Secara struktur pembahasan KHI yang menempatkan status hukum perkawinan beda agama dalam bab yang membahas tentang "larangan perkawinan", jika dicermati, dapat dikategorikan sebagai pembaharuan yang cukup berani.

Pembaharuan tersebut tentu ditetapkan setelah melalui penyatuan pendapat melalui beberapa jalur, yaitu: 1) Jalur penelaahan kitab-kitab fikih, yang dilakukan dengan melibatkan tujuh IAIN yang tersebar di seluruh Indonesia, khususnya Fakultas Syariah. Dalam penelaahan kitab-kitab fikih tersebut, para pihak telah melakukannya dengan melakukan penelitian terhadap sejumlah kitab-kitab induk fikih dari berbagai kecenderungan mazhab yang ada; 2) Jalur wawancara dengan ulama-ulama yang mempunyai keahlian di bidang hukum Islam (fikih) yang tersebar di sepuluh lokasi wilayah PTA, yaitu: Banda Aceh, Medan, Padang, Palembang, Bandung, Surakarta, Surabaya, Banjarmasin, Ujung Pandang (Makassar), dan Mataram; 3) Jalur Yuriprudensi Peradilan Agama, dilakukan di Direktorat Pembinaan Badan Peradilan Agama Islam terhadap sepuluh Himpunan Putusan PA; 4) Jalur studi banding ke Marokko, Turki dan Mesir oleh tim dari Kemenag RI (H. Marani Basran dan Mukhtar Zarkasyi). ${ }^{6}$

\footnotetext{
5 Sri Wahyuni, Kontroversi Perkawinan Beda Agama di Indonesia, h 196

6 Direktorat Pembinaan Badan Peradilan Agama Islam, Direktorat Jenderal Pembinaan Kelembagan Islam Departemen Agama, Kenang-kenangan Seabad Peradilan Agama di Indonesia, Jakarta, 1985, hlm 166-168.
} 


\section{ANALISIS TERHADAP PERKAWINAN BEDA AGAMA}

Dalam menganalisi kontroversi perkawinan beda agama seperti yang telah dipaparkan di atas, diperlukan suatu metode yang komprehensif kontekstual agar dapat menarik benang merah dari permalahan tersebut.

1. Konteroversi perkawinan beda agama dalam UUP tidak lepas dari konteks historisnya, dimana proses penyusunan dan perumusan UUP merupakan hasil tawar menawar dari berbagai kepentingan di antara fraksi-fraksi yang ada ketika itu, khususnya fraksi ABRI dan PPP, sehingga aspirasi masyarakat belum mndapatkan respon yang memadai, meskipun telah berusaha untuk meminimalisir dengan memilih sistem unifikasi terbatas yaitu dengan mengadakan kesatuan ketentuan-ketentuan di dalam perkawinan dengan memberi tempat bagi kekhususan yang dizinkan oleh agama masing-masing.

2. Perkawinan wanita muslimah dengan pria non muslim, yang menurut perspektif fikih, fatwa MUI dan Majlis Tarjih serta KHI diharamkan. Apabila dianalisis dengan penelaahan yang digunakan pihak-pihak yang tidak setuju dengan status hukum tersebut, maka akan diklaim kalau masalah tersebut tidak dilandasi dengan dalil yang jelas, baik dari Al-Quran maupun hadis Nabi, sehingga masuk dalam wilayah ijtihad. Padahal ijtihad yang dilakukan untuk menemukan dasar hukum dari suatu masalah tidak bias terlepas dengan situasi dan kondisi sosial pada saat itu, yang merupakan diminasi masyarakat laki-laki dan masyarakat perempuan belum begitu maju seperti saat ini, sehingga klaim keharaman perkawinan wanita muslim dengan laki-laki non muslim selalu dikaitkan kekhawatiran akan keyakinan dan akidahnya yang akan terpengaruh dengan keyakinan adan akidah si suami. Demikian halnya dengan pendidikan anak-anak hasil perkawinan tersebut, dikhawatirkan akan lebih banyak mengikuti keyakinan dan agama bapaknya, sehingga landasan yang dijadikan patokan dalam menetapkan hukum adalah kaidah sadd az-zari'ah (tindakan preventif) yang menurut mereka adalah suatu kekhawatiran yang dilandasi dengan asumsi-asumsi tanpa pengajuan bukti material yang meyakinkan, sehingga apa yang diputuskan berdasarkan asumsi tersebut berbeda dengan kenyataan yang ada di lapangan.

3. Kebolehan perkawinan beda agama yang diwacanakan oleh Tim Persamaan Gender yang didasarkan pada pemaknaan hermeneutik dan hasil penelitian lapangan, dalam beberapa hal dapat dianggap rasional. Namun mereka kurang memperhatikan 17 bahwa 
upaya pemerintah tersebut adalah untuk menghilangkan perbedaan pendapat dalam masalah tersebut dan sekaligus menjaga agama dan kepercayaan serta mewujudkan kemaslahatan masyarakat. Tindakan tersebut sesuai dengan kaidah fikih: (Keputusan hakim/ pemerintah dalam masalah ijtihad menghapuskan perbedaan pendapat), dan (Tindakan pemerinah terhadap rakyatnya harus sesuai dengan kemaslahatan). Selain itu, yang mendaari kebijakan ini adalah sadd adz-dzari'ah, yaitu tindakan preventif untuk mencegah terjadinya kemurtadan dan kehancuran rumah tangga akibat perkainan beda agama, hal itu sesuai dengan kaidah: (menghindari kerusakan lebih didahulkan dari menarik kemaslahatan). Terkait dengan hasil penelitian yang menemuan fakta bahwa bahwa perkawinan laki-laki muslim dengan wanita non muslim mengahasilkan 50\% anak beragama Islam. Sementara perkawinan laki-laki non muslim dengan wanita muslim menghasilkan 77- 79\% beragama Islam. Hasil penelitian tersebut tidak sepenuhnya benar, karena pendidikan pasangan yang melakukan perkawinan beda agama 50\% lebih dilakukan oleh orang desa yang pendidikannya rendah (bahkan ada yang tidak tamat SD). ${ }^{7}$ Ada hasil penelitian lain menyebutkan bahwa rendahnya tingkat keagamaan suami atau isteri menyebabkan persoalan agama di antara mereka buka merupakan prioritas yang utama, karena kebahagiaan dalam kehidupan rumah tangga bagi perkawinan beda agama adalah terpenuhinya kewajiban suami isteri, yang diukur dari kebutuhan ekonomi, psikologis dan spiritual. ${ }^{8}$ Dalam penelitian tersebut juga ditemkan bahwa setelah berumah tangga, salah satu pasangan yang tingkat keagamaannya semula rendah akan semakin rendah, mereka hanya mengikuti hanya mengikuti ibadah yang bersifat tradisi (syawalan dan natal) tanpa melakkan ibadah-ibadh yang bersifat ritual, sehingga tingkat keagamaan tersebut berpengaruh kepada anakanaknya dan mereka akan memilih agam salah satu orang tua yang di pandang lebih kuat.

\section{KESIMPULAN}

Berdasarkan pembahasan-pembahasan yang dilakukan dapat disimpulkan sebagai berikut:

\footnotetext{
7 Mudiarti Trisnaningsih, Relevansi Kepastian Hukum dalam Mengatur Perkawinan Beda Agama di Indonesia, h. 39

${ }^{8}$ Ermi Suhasti, Harmoni Keluarga Beda Agama di Mlati Sleman, Yogyakarta, Asy-Syir'ah, Jurnal Ilmu Syariah, Vol. 45, No. 1, 2011 h. 1249
} 
1. Dalam perjalanan historisnya, persoalan perkawinan beda agama selalu menjadi kontroversi di kalangan umat Islam sampai saat sekarang ini. Hal itu dikarenakan adanya pihak yang menganggap perkawinan beda agama merupakan sesuatu yang sudah final dan sangat tabu, sementara di sisi lain pihak-pihak yang ingin melakukan rasionalisasi masalah tersebut sesuai dengan perkembangan zaman.

2. Untuk menentukan status hukum perkawinan beda agama perlu dilakukan pembacaan ulang terhadap teks-teks yang berpotensi memperkuat dan memperkaya keputusan yang akan diambil dengan menggunakan pendekatan komprehensif, kontekstual dan multi analisis. Di samping memperhatikan hail-hasil penelitian terhadap pasangan beda agama, sehingga keputusan itu dapat memenuhi kebutuhan masyarakat yang multikultural tanpa menafikan dokterin-doktrin dan kebenaran agama serta kearifan lokal yang ada.

\section{DAFTAR PUSTAKA}

Ahmad Shalaby, Kehidupan Sosial Dalam Pemikiran Islam, Amzah, Jakarta, 2001

Abdul Azis Dahlan, Ensiklopedia Hukum Islam, Ictiyar Baru Van Hoeve, Jakarta, 2006.

Direktorat Pembinaan Badan Peradilan Agama Islam, Direktorat Jenderal Pembinaan Kelembagan Islam Departemen Agama, Kenang-kenangan Seabad Peradilan Agama di Indonesia, Jakarta, 1985.

Ermi Suhasti, Harmoni Keluarga Beda Agama di Mlati Sleman, Yogyakarta, Asy-Syir'ah, Jurnal Ilmu Syariah, Vol. 45, No. 1, 2011.

Musafir Husain Aj-jahrani, Poligami Dalam Berbagai Persepsi, Gema Insani Pres, Jakarta, 1996

Mudiarti Trisnaningsih, Relevansi Kepastian Hukum dalam Mengatur Perkawinan Beda Agama di Indonesia Bandung, 2007

Sri Wahyuni, Kontroversi Perkawinan Beda Agama di Indonesia Media Syariah, Vol . XIII. 2011

UUP No. 1 thn 1974 dan Abdul Halim Berkatullah dan Teguh Prasetyo, Hukum Islam Menjawab Tantangan Zaman yang Terus Berkembang, Yogyakarta, Pustaka Pelajar, 2006 